\title{
Re-evaluation of Korean Effluent Concentration Limits and Comparative Analysis
}

\author{
Won Tae Hwang, Joeun Lee*, Dahye Kwon, Eun Han Kim, Moon Hee Han \\ Korea Atomic Energy Research Institute, Daejeon, Korea
}

\section{Technical Paper}

Received July 4, 2018

Revision August 28, 2018

Accepted September 12, 2018

Corresponding author: Joeun Lee

Korea Atomic Energy Research Institute, 111 Daedeok-daero 989beon-gil,

Yuseong-gu, Daejeon 34057, Korea

Tel: +82-42-868-8945

Fax: $+82-42-868-2370$

E-mail: leejoeun@kaeri.re.kr

This is an Open-Access article distributed under the terms of the Creative Commons Attribution NonCommercial License (http://creativecommons.org/ licenses/by-nc/4.0) which permits unrestricted noncommercial use, distribution, and reproduction in any medium, provided the original work is properly cited.

Copyright $\odot$ 2018The Korean Association for Radiation Protection

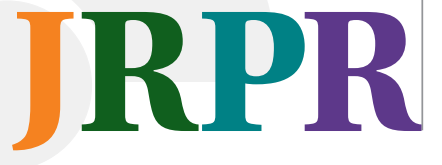

Background: Effluent Concentration Limits (ECLs) were re-evaluated via direct calculation using dose coefficients based on radiation protection quantity introduced in Korea and the intrinsic breathing rates of Korean residents.

Materials and Methods: The re-evaluated ECLs were compared with the domestic standards given in the Notice of the Nuclear Safety and Security Commission (NSSC), as well as with ECLs specified in the Code of Federal Regulations (CFR).

Results and Discussion: The relative ratios of the re-evaluated ECLs to the currently applied domestic standards differed depending on the radionuclide type, but it was clearly shown that, for tritium $\left({ }^{3} \mathrm{H}\right)$ and radiocarbon $\left({ }^{14} \mathrm{C}\right)$, which significantly affect radiological dose to the public during the normal operation of nuclear power plants, the re-evaluated ECLs were higher than the domestic standards. This implies that Korean standards are relatively conservative.

Conclusion: The re-evaluated results for each age group showed that ${ }^{131} \mathrm{I}$ (radioiodine), one of the significant radionuclides, had the lowest values, but nonetheless, the domestic standards for radioiodine were lower than the ECLs given in the CFR and the re-evaluated ECLs via a method given in the CFR.

Keywords: Effluent Concentration Limit (ECL), Routine release, NSSC’s Notice, 10CFR20

\section{Introduction}

All radionuclides and their chemical forms have designated Effluent Concentration Limits (ECLs) to protect the public against any health hazards arising from radioactive materials, as specified in Column 5 of Appendix 3 of the Public Notice No. 2017-36 (Standards for Radiation Protection, Etc.) by Korea's Nuclear Safety and Security Commission (NSSC). ECLs are determined by annual dose limits to individuals based on inhalation of airborne radioactive materials. In Korea, ECLs were initially set and enacted by directly adopting the values specified in the Code of Federal Regulations (CFR; 10CFR Part 20 Appendix B, 1991), but a revision was made with the country's adoption of the 1990 recommendations of the International Commission of Radiological Protection (ICRP-60) on radiological protection. Rather than being directly calculated based on the fundamental ECL concepts, as mentioned above, the Korean ECLs are estimated from Derived Air Concentrations (DACs) for radiation workers in an indirect and approximate manner by considering the difference between radiation workers and the public in their annual dose limits, breathing rate, activity time, and sensitivity to radia- 
tion exposure by age. Similarly, the ECLs given in the CFR (the CFR ECLs) are also indirectly estimated from radiation workers' DACs, instead of being directly calculated based on dose limits for the public. It should be noted that, unlike in Korea, the US has adopted its radiation protection quantity based on the 1977 recommendations of the ICRP (ICRP-26). Therefore, it is necessary to assess whether the current domestic ECLs have been properly determined using various methods.

In the present study, ECLs were directly calculated, reflecting dose coefficients based on radiation protection quantity introduced in Korea, and the intrinsic breathing rates of Korean residents. These results were compared with the current domestic limits, as well as with the CFR ECLs

\section{Materials and Methods}

ECLs are defined as the air concentration of radioactive materials which corresponds to the annual dose limit, i.e., $1 \mathrm{mSv} \cdot \mathrm{yr}^{-1}$ of the effective dose equivalent. In Korea, these ECLs were enacted following the NSSC's Notice, which aimed to limit the stochastic radiation-induced health effects from inhalation of airborne radioactive materials. Considering that the operation of nuclear facilities could entail the inevitable release of various radioactive materials to the environment to a slight extent, ECLs are designated for each radionuclide, reflecting their respective air concentration, which is equivalent to the annual dose limit. Therefore, for multiple-radionuclide releases, the annual dose limits are appropriately managed using Equation 1 below, to ensure they are not exceeded [1].

$$
\sum_{i}\left(\frac{C_{\mathrm{i}}}{E C L_{\mathrm{i}}}\right) \leq 1
$$

Where,

$$
E C L_{\mathrm{i}} \text { : Effluent concentration limit for radionuclide } \mathrm{i}\left(\mathrm{Bq} \cdot \mathrm{m}^{-3}\right)
$$$$
C_{\text {i: }} \text { Air concentration of radionuclide } \mathrm{i}\left(\mathrm{Bq} \cdot \mathrm{m}^{-3}\right)
$$

In the US, the 1977 recommendations of the ICRP (ICRP-26) have been adopted, and the annual dose limit has been defined as $1 \mathrm{mSv} \cdot \mathrm{yr}^{-1}$ of the effective dose equivalent under the CFR. As in Korea, ECLs stated in the CFR are indirectly estimated from radiation workers' DACs, reflecting the difference between radiation workers and the public in their annual dose limits and behavior. Also, the annual dose limit for younger age group who are more sensitive to radiation exposure, is set at one half of that of adults $\left(0.5 \mathrm{mSv} \cdot \mathrm{yr}^{-1}\right.$ of the effective dose equivalent). The 1990 recommendations of the ICRP (ICRP-60) specify the dose coefficients for 6 age groups of the public (3-month-old, 1-year-old, 5-year-old, 10-yearold, 15-year-old, and adult). In Korea, the breathing rates for 4 age groups (infant, child, teenager, and adult) were investigated and used for the assessment of radiological dose to the public from nuclear facilities [2]. Here, the infant, child, teenager, and adult age groups correspond to the 3-month-old, 5 -year-old, 15-year-old, and adult age groups proposed by the ICRP, respectively. ${ }^{1)}$

Based on its conceptual definition, the ECL can be directly calculated using the following equation.

$$
E C L_{\mathrm{i}, \mathrm{j}}=\frac{D L}{\left(B r_{\mathrm{j}} D C_{\mathrm{i}, \mathrm{j}}\right)}
$$

Where,

$E C L_{\mathrm{i}, \mathrm{j}}$ : Effluent Concentration Limit for radionuclide i and age group $\mathrm{j}\left(\mathrm{Bq} \cdot \mathrm{m}^{-3}\right)$

$D L$ : Annual dose limit set for ECL evaluation $\left(\mathrm{mSv} \cdot \mathrm{yr}^{-1}\right)$

$B r$ : Breathing rate for age group $\mathrm{j}\left(\mathrm{m}^{3} \cdot \mathrm{yr}^{-1}\right)$

$D C_{\mathrm{i}, \mathrm{j}}$ : Dose coefficient by inhalation of radionuclide i for age group $\mathrm{j}\left(\mathrm{mSv} \cdot \mathrm{Bq}^{-1}\right)$

Table 1 contains multiple sets of data, including the intrinsic breathing rates of domestic residents by age group; types of radionuclides possibly released to the environment during the normal operation of nuclear power plants, as specified in their license and permit documents; and their basic chemical forms and dose coefficients, applied to off-site radiological dose assessments $[3,4]$. Here, inert gasses are excluded from the list of radionuclides possibly released to the environment during the normal operation of nuclear power plants, because inert-gas inhalation is a minor exposure pathway compared to others in off-site radiological dose assessments [5].

Dose coefficients from inhalation and their health effects on the human body differ according to the chemical form of the radioactive materials. In off-site radiological dose assessment, tritium is set as a form of HTO; radiocarbon, as a form of $\mathrm{CO}_{2}$; and radioiodine, as an elemental type. Nuclear-related international organizations have proposed recommended chemical forms if radionuclide information is not available, and this information is used when off-site radiological dose are evaluated in Korea.

1) Korea Institute of Nuclear Safety. Development of methodology for radiological emergency and environmental assessment : ODCM guideline \& INDAC user manual. KINS GR-199. 2000;1-329. 
Table 1. Breathing Rates and Dose Coefficients According to Age Groups to be Applied to the Korean Off-site Radiological Dose Calculations [2]

\begin{tabular}{|c|c|c|c|c|c|c|}
\hline \multirow{2}{*}{ Parameter } & & & \multicolumn{4}{|c|}{ Age group } \\
\hline & & & \multirow{2}{*}{$\begin{array}{l}\text { Infant } \\
1,400\end{array}$} & \multirow{2}{*}{$\begin{array}{l}\text { Child } \\
6,700\end{array}$} & \multirow{2}{*}{$\begin{array}{r}\text { Teen } \\
7,900\end{array}$} & \multirow{2}{*}{$\begin{array}{l}\text { Adult } \\
7,400\end{array}$} \\
\hline Breathing rate ( $\mathrm{m}$ & & & & & & \\
\hline \multirow{25}{*}{$\begin{array}{l}\text { Dose coefficient } \\
\left(\mathrm{mSv} \cdot \mathrm{Bq}^{-1}\right)\end{array}$} & ${ }^{3} \mathrm{H}$ & HTO & 6.40E-08 & 3.10E-08 & 1.80E-08 & 1.80E-08 \\
\hline & ${ }^{14} \mathrm{C}$ & $\mathrm{CO}_{2}$ & 1.90E-08 & 1.10E-08 & 6.30E-09 & $6.20 \mathrm{E}-09$ \\
\hline & ${ }^{51} \mathrm{Cr}$ & S & 2.60E-07 & $1.00 \mathrm{E}-07$ & 4.50E-08 & 3.70E-08 \\
\hline & ${ }^{54} \mathrm{Mn}$ & M & 7.50E-06 & 3.80E-06 & 1.90E-06 & 1.50E-06 \\
\hline & ${ }^{57} \mathrm{Co}$ & M & 2.80E-06 & $3.50 \mathrm{E}-06$ & 6.70E-07 & 5.50E-07 \\
\hline & ${ }^{58} \mathrm{Co}$ & M & 7.30E-06 & $3.50 \mathrm{E}-06$ & 2.00E-06 & 1.60E-06 \\
\hline & ${ }^{60} \mathrm{Co}$ & M & 4.20E-05 & 2.10E-05 & 1.20E-05 & 1.00E-05 \\
\hline & ${ }^{59} \mathrm{Fe}$ & M & 1.80E-05 & 7.90E-06 & 4.60E-06 & 3.70E-06 \\
\hline & ${ }^{89} \mathrm{Sr}$ & $\mathrm{F}$ & 1.50E-05 & $3.20 \mathrm{E}-06$ & 1.70E-06 & 1.00E-06 \\
\hline & ${ }^{90} \mathrm{Sr}$ & $\mathrm{F}$ & 1.30E-04 & 3.10E-05 & 5.30E-05 & 2.40E-05 \\
\hline & ${ }^{95} \mathrm{Zr}$ & M & 2.00E-05 & $9.70 \mathrm{E}-06$ & 5.90E-06 & 4.80E-06 \\
\hline & ${ }^{95} \mathrm{Nb}$ & M & 6.80E-06 & 3.10E-06 & 1.90E-06 & 1.50E-06 \\
\hline & ${ }^{103} \mathrm{Ru}$ & M & 1.10E-05 & 5.00E-06 & 3.00E-06 & 2.40E-06 \\
\hline & ${ }^{106} \mathrm{Ru}$ & M & 1.40E-04 & $6.40 \mathrm{E}-05$ & 3.10E-05 & 2.80E-05 \\
\hline & ${ }^{125} \mathrm{Sb}$ & M & 2.00E-05 & 1.00E-05 & 5.80E-06 & 4.80E-06 \\
\hline & ${ }^{131} \mid$ & e & 1.70E-04 & $9.40 \mathrm{E}-05$ & 3.10E-05 & 2.00E-05 \\
\hline & $132 \mid$ & e & 2.80E-06 & 1.30E-06 & 4.30E-07 & 3.10E-07 \\
\hline & 133 & e & 4.50E-05 & 2.10E-05 & 6.30E-06 & 4.00E-06 \\
\hline & ${ }^{134} \mid$ & e & 8.70E-07 & $3.90 \mathrm{E}-07$ & 1.60E-07 & 1.50E-07 \\
\hline & 135 & e & 9.70E-06 & 4.50E-06 & $1.40 \mathrm{E}-06$ & $9.20 \mathrm{E}-07$ \\
\hline & ${ }^{134} \mathrm{Cs}$ & F & 1.10E-05 & 5.20E-06 & 6.30E-06 & 6.60E-06 \\
\hline & ${ }^{136} \mathrm{Cs}$ & F & 7.30E-06 & 2.90E-06 & 1.40E-06 & 1.20E-06 \\
\hline & ${ }^{137} \mathrm{Cs}$ & $\mathrm{F}$ & 8.80E-06 & 3.60E-06 & 4.40E-06 & 4.60E-06 \\
\hline & ${ }^{140} \mathrm{Ba}$ & $M$ & 2.70E-05 & 1.10E-05 & 6.20E-06 & 5.10E-06 \\
\hline & ${ }^{141} \mathrm{Ce}$ & M & 1.30E-05 & 6.30E-06 & 4.10E-06 & 3.20E-06 \\
\hline
\end{tabular}

F, Fast; M, Moderate; S, Slow; e, elemental.

\section{Results and Discussion}

ECLs were re-evaluated via direct calculation using intrinsic breathing rates of domestic residents for radionuclides possibly released to the environment during the normal operation of nuclear power plants, as specified in their license and permit documents.

Currently applied ECLs in Korea (NSSC's Notice) and the US (10CFR20) were compared, as shown in Table 2. Unlike in Korea, the US has adopted the 1977 recommendations of the ICRP (ICRP-26). Accordingly, the US designation of D (Day), W (Week), and Y (Year) regarding pulmonary absorption modes correspond to the $\mathrm{F}$ (Fast), M (Moderate), and S (Slow) given in the 1990 recommendations of the ICRP (ICRP-60). Among radioactive materials released during the normal operation of nuclear power plants, tritium $\left({ }^{3} \mathrm{H}\right)$, radiocarbon $\left({ }^{14} \mathrm{C}\right)$, and iodine isotopes $\left({ }^{131} \mathrm{I}\right)$ are those which have significant effects on off-site radiological dose assess- ments. It should be noted that ECLs for these three radionuclide types are set lower in Korea than in the US. The lower ECLs in Korea means that the country uses more conservative standards. In the case of ${ }^{131} \mathrm{I}$, in particular, the ECL is set approximately 2.5 times higher in the US than in Korea. This large discrepancy comes from the fact that the recommended chemical form for radioiodine is the elemental type in Korea. In contrast, in the US, particle type D is applied as a default option for all chemical forms; and a separate standard for the elemental type is not available. According to the 1990 recommendations of the ICRP, the elemental-type radioiodine has a dose coefficient approximately 2.7 times lower than the particle type F radioiodine (which corresponds to particle type D under the 1977 recommendations of the ICRP). For specific radionuclides, such as Sr and Cs, ECLs are set lower in the US than in Korea, but these radionuclides have relatively less significant in off-site radiological dose assessments, compared to ${ }^{3} \mathrm{H},{ }^{14} \mathrm{C}$, and ${ }^{131} \mathrm{I}$. 
Table 2. Comparison of Effluent Concentration Limits Documented in NSSC's Notice and 10CFR20

\begin{tabular}{lccc}
\hline Radionuclide & \multicolumn{2}{c}{ Effluent Concentration Limits $\left(\mathrm{Bq} \cdot \mathrm{m}^{-3}\right)$} & $\begin{array}{c}\text { Relative ratio } \\
\left(\mathrm{B} \cdot \mathrm{A}^{-1}\right)\end{array}$ \\
\cline { 2 - 3 } & NSSC's Notice $(\mathrm{A})$ & $10 \mathrm{CFR} 20(\mathrm{~B})$ & 1.23 \\
\hline${ }^{3} \mathrm{H}$ & $3.00 \mathrm{E}+03$ & $3.70 \mathrm{E}+03$ & 1.11 \\
${ }^{14} \mathrm{C}$ & $1.00 \mathrm{E}+04$ & $1.11 \mathrm{E}+04$ & 0.56 \\
${ }^{51} \mathrm{Cr}$ & $2.00 \mathrm{E}+03$ & $1.11 \mathrm{E}+03$ & 0.74 \\
${ }^{54} \mathrm{Mn}$ & $5.00 \mathrm{E}+01$ & $3.70 \mathrm{E}+01$ & 1.48 \\
${ }^{57} \mathrm{Co}$ & $1.00 \mathrm{E}+02$ & $1.48 \mathrm{E}+02$ & 1.48 \\
${ }^{58} \mathrm{Co}$ & $5.00 \mathrm{E}+01$ & $7.40 \mathrm{E}+01$ & 1.06 \\
${ }^{60} \mathrm{Co}$ & $7.00 \mathrm{E}+00$ & $7.40 \mathrm{E}+00$ & 1.30 \\
${ }^{59} \mathrm{Fe}$ & $2.00 \mathrm{E}+01$ & $2.59 \mathrm{E}+01$ & 0.53 \\
${ }^{89} \mathrm{Sr}$ & $7.00 \mathrm{E}+01$ & $3.70 \mathrm{E}+01$ & 0.37 \\
${ }^{90} \mathrm{Sr}$ & $3.00 \mathrm{E}+00$ & $1.11 \mathrm{E}+00$ & 0.93 \\
${ }^{95} \mathrm{Zr}$ & $2.00 \mathrm{E}+01$ & $1.85 \mathrm{E}+01$ & 1.48 \\
${ }^{95} \mathrm{Nb}$ & $5.00 \mathrm{E}+01$ & $7.40 \mathrm{E}+01$ & 1.23 \\
${ }^{103} \mathrm{Ru}$ & $3.00 \mathrm{E}+01$ & $3.70 \mathrm{E}+01$ & 0.99 \\
${ }^{106} \mathrm{Ru}$ & $3.00 \mathrm{E}+00$ & $2.96 \mathrm{E}+00$ & 1.30 \\
${ }^{125} \mathrm{Sb}$ & $2.00 \mathrm{E}+01$ & $2.59 \mathrm{E}+01$ & 2.47 \\
${ }^{131} \mathrm{I}$ & $3.00 \mathrm{E}+00$ & $7.40 \mathrm{E}+00$ & 3.70 \\
${ }^{132}$ & $2.00 \mathrm{E}+02$ & $7.40 \mathrm{E}+02$ & 1.85 \\
${ }^{133}$ & $2.00 \mathrm{E}+01$ & $3.70 \mathrm{E}+01$ & 4.44 \\
${ }^{134} \mathrm{I}$ & $5.00 \mathrm{E}+02$ & $2.22 \mathrm{E}+03$ & 2.78 \\
${ }^{135}$ & $8.00 \mathrm{E}+01$ & $2.22 \mathrm{E}+02$ & 0.74 \\
${ }^{134} \mathrm{Cs}$ & $1.00 \mathrm{E}+01$ & $7.40 \mathrm{E}+00$ & 0.67 \\
${ }^{136} \mathrm{Cs}$ & $5.00 \mathrm{E}+01$ & $3.33 \mathrm{E}+01$ & 0.74 \\
${ }^{137} \mathrm{Cs}$ & $1.00 \mathrm{E}+01$ & $7.40 \mathrm{E}+00$ & 1.06 \\
${ }^{140} \mathrm{Ba}$ & $7.00 \mathrm{E}+01$ & $7.40 \mathrm{E}+01$ & 1.85 \\
${ }^{141} \mathrm{Ce}$ & $2.00 \mathrm{E}+01$ & $3.70 \mathrm{E}+01$ & \\
\hline & & & \\
\hline
\end{tabular}

These Korean and CFR ECLs are estimated from radiation workers' DAC in an indirect and approximate manner, considering the difference between radiation workers and the public in their annual dose limits, breathing rates, and activity time. The reliability of these indirect estimation results, however, may be questioned because the method only reflects the ratio of approximately averaged differences, instead of considering in detail differences arising from the different characteristics of each radionuclide type and age group. To overcome this limitation, in the present study, ECLs were directly calculated, based on their conceptual definition, to reflect the intrinsic breathing rates of Korean residents and dose coefficients based on the radiation protection doses introduced in Korea.

To that end, two direct calculation methods are proposed. The first one is a method described in the CFR (10CFR20), where ECLs are calculated based on the annual dose limit for the younger age group $\left(0.5 \mathrm{mSv} \cdot \mathrm{yr}^{-1}\right)$ which is set to be one half of that of the adult group $\left(1 \mathrm{mSv} \cdot \mathrm{yr}^{-1}\right)$, reflecting this younger age group's physical sensitivity to radiation expo-
Table 3. Comparison of Effluent Concentration Limits Documented in NSSC's Notice and Re-evaluated Based on the Method Described in 10CFR20 (Method-1)

\begin{tabular}{lccc}
\hline \multirow{2}{*}{ Radionuclide } & \multicolumn{2}{c}{ Effluent Concentration Limits $\left(\mathrm{Bq} \cdot \mathrm{m}^{-3}\right)$} & $\begin{array}{c}\text { Relative ratio } \\
\left(\mathrm{B} \cdot \mathrm{A}^{-1}\right)\end{array}$ \\
\cline { 2 - 3 } & NSSC's Notice $(\mathrm{A})$ & Method $-1(\mathrm{~B})$ & \\
\hline${ }^{3} \mathrm{H}$ & $3.00 \mathrm{E}+03$ & $3.75 \mathrm{E}+03$ & 1.25 \\
${ }^{14} \mathrm{C}$ & $1.00 \mathrm{E}+04$ & $1.09 \mathrm{E}+04$ & 1.09 \\
${ }^{51} \mathrm{Cr}$ & $2.00 \mathrm{E}+03$ & $1.83 \mathrm{E}+03$ & 0.91 \\
${ }^{54} \mathrm{Mn}$ & $5.00 \mathrm{E}+01$ & $4.50 \mathrm{E}+01$ & 0.90 \\
${ }^{57} \mathrm{Co}$ & $1.00 \mathrm{E}+02$ & $1.23 \mathrm{E}+02$ & 1.23 \\
${ }^{58} \mathrm{Co}$ & $5.00 \mathrm{E}+01$ & $4.22 \mathrm{E}+01$ & 0.84 \\
${ }^{60} \mathrm{Co}$ & $7.00 \mathrm{E}+00$ & $6.76 \mathrm{E}+00$ & 0.97 \\
${ }^{59} \mathrm{Fe}$ & $2.00 \mathrm{E}+01$ & $1.83 \mathrm{E}+01$ & 0.91 \\
${ }^{89} \mathrm{Sr}$ & $7.00 \mathrm{E}+01$ & $6.76 \mathrm{E}+01$ & 0.97 \\
${ }^{90} \mathrm{Sr}$ & $3.00 \mathrm{E}+00$ & $2.82 \mathrm{E}+00$ & 0.94 \\
${ }^{95} \mathrm{Zr}$ & $2.00 \mathrm{E}+01$ & $1.41 \mathrm{E}+01$ & 0.70 \\
${ }^{95} \mathrm{Nb}$ & $5.00 \mathrm{E}+01$ & $4.50 \mathrm{E}+01$ & 0.90 \\
${ }^{103} \mathrm{Ru}$ & $3.00 \mathrm{E}+01$ & $2.82 \mathrm{E}+01$ & 0.94 \\
${ }^{106} \mathrm{Ru}$ & $3.00 \mathrm{E}+00$ & $2.41 \mathrm{E}+00$ & 0.80 \\
${ }^{125} \mathrm{Sb}$ & $2.00 \mathrm{E}+01$ & $1.41 \mathrm{E}+01$ & 0.70 \\
${ }^{131} \mathrm{I}$ & $3.00 \mathrm{E}+00$ & $3.38 \mathrm{E}+00$ & 1.13 \\
${ }^{132}$ & $2.00 \mathrm{E}+02$ & $2.18 \mathrm{E}+02$ & 1.09 \\
${ }^{133} \mathrm{I}$ & $2.00 \mathrm{E}+01$ & $1.69 \mathrm{E}+01$ & 0.84 \\
${ }^{134} \mathrm{I}$ & $5.00 \mathrm{E}+02$ & $4.50 \mathrm{E}+02$ & 0.90 \\
${ }^{135}$ & $8.00 \mathrm{E}+01$ & $7.34 \mathrm{E}+01$ & 0.92 \\
${ }^{134} \mathrm{Cs}$ & $1.00 \mathrm{E}+01$ & $1.02 \mathrm{E}+01$ & 1.02 \\
${ }^{136} \mathrm{Cs}$ & $5.00 \mathrm{E}+01$ & $5.63 \mathrm{E}+01$ & 1.13 \\
${ }^{137} \mathrm{Cs}$ & $1.00 \mathrm{E}+01$ & $1.47 \mathrm{E}+01$ & 1.47 \\
${ }^{140} \mathrm{Ba}$ & $7.00 \mathrm{E}+01$ & $1.32 \mathrm{E}+01$ & 0.19 \\
${ }^{141} \mathrm{Ce}$ & $2.00 \mathrm{E}+01$ & $2.11 \mathrm{E}+01$ & 1.06 \\
\hline
\end{tabular}

sure. The second method calculates ECLs using characteristics data acquired from various age groups and evaluates them with regard to the annual dose limit of $1 \mathrm{mSv} \cdot \mathrm{yr}^{-1}$. Among them, the lowest value, which is the most conservative, is selected.

ECLs that were re-evaluated via the method described in the CFR reflecting intrinsic breathing rates of Korean adults and radiation protection quantity introduced in Korea are summarized and compared with the currently applied domestic ECLs, as shown in Table 3. For tritium $\left({ }^{3} \mathrm{H}\right)$ and radiocarbon $\left({ }^{14} \mathrm{C}\right)$, which significantly affect off-site radiological dose assessments, the domestic standards are lower than the re-evaluated results via the CFR method. With regard to radioiodine, the domestic standards are lower than the reevaluated results for ${ }^{131} I$ and ${ }^{132} I$, while the domestic standards are higher for ${ }^{133} \mathrm{I},{ }^{134} \mathrm{I}$, and ${ }^{135} \mathrm{I}$.

ECLs that were re-evaluated via the method described in the CFR reflecting the intrinsic breathing rates of each age group of Korean residents and radiation protection quantity introduced in Korea were summarized and compared with 
Table 4. Comparison of Effluent Concentration Limits Documented in NSSC's Notice and Re-evaluated in Consideration of Age Groups (Method-2)

\begin{tabular}{|c|c|c|c|c|c|c|c|}
\hline \multirow{2}{*}{ Radionuclide } & \multirow{2}{*}{$\begin{array}{l}\text { NSSC's Notice } \\
\text { (A) }\end{array}$} & \multicolumn{5}{|c|}{ Method-2 } & \multirow{2}{*}{$\begin{array}{l}\text { Relative ratio } \\
\qquad\left(B \cdot A^{-1}\right)\end{array}$} \\
\hline & & Infant & Child & Teen & Adult & Minimum (B) & \\
\hline${ }^{3} \mathrm{H}$ & $3.00 \mathrm{E}+03$ & $1.12 \mathrm{E}+04$ & $4.81 \mathrm{E}+03$ & $7.03 \mathrm{E}+03$ & $7.51 \mathrm{E}+03$ & $4.81 \mathrm{E}+03$ & 1.60 \\
\hline${ }^{14} \mathrm{C}$ & $1.00 \mathrm{E}+04$ & $3.76 \mathrm{E}+04$ & $1.36 \mathrm{E}+04$ & $2.01 E+04$ & $2.18 \mathrm{E}+04$ & $1.36 \mathrm{E}+04$ & 1.36 \\
\hline${ }^{51} \mathrm{Cr}$ & $2.00 \mathrm{E}+03$ & $2.75 E+03$ & $1.49 \mathrm{E}+03$ & $2.81 E+03$ & $3.65 \mathrm{E}+03$ & $1.49 \mathrm{E}+03$ & 0.75 \\
\hline${ }^{54} \mathrm{Mn}$ & $5.00 \mathrm{E}+01$ & $9.52 \mathrm{E}+01$ & $3.93 \mathrm{E}+01$ & $6.66 \mathrm{E}+01$ & $9.01 E+01$ & $3.93 \mathrm{E}+01$ & 0.79 \\
\hline${ }^{57} \mathrm{Co}$ & $1.00 \mathrm{E}+02$ & $2.55 \mathrm{E}+02$ & $4.26 \mathrm{E}+01$ & $1.89 \mathrm{E}+02$ & $2.46 \mathrm{E}+02$ & $4.26 \mathrm{E}+01$ & 0.43 \\
\hline${ }^{58} \mathrm{Co}$ & $5.00 \mathrm{E}+01$ & $9.78 \mathrm{E}+01$ & $4.26 \mathrm{E}+01$ & $6.33 \mathrm{E}+01$ & $8.45 \mathrm{E}+01$ & $4.26 \mathrm{E}+01$ & 0.85 \\
\hline${ }^{60} \mathrm{Co}$ & $7.00 \mathrm{E}+00$ & $1.70 \mathrm{E}+01$ & $7.11 \mathrm{E}+00$ & $1.05 \mathrm{E}+01$ & $1.35 \mathrm{E}+01$ & $7.11 \mathrm{E}+00$ & 1.02 \\
\hline${ }^{59} \mathrm{Fe}$ & $2.00 \mathrm{E}+01$ & $3.97 \mathrm{E}+01$ & $1.89 \mathrm{E}+01$ & $2.75 \mathrm{E}+01$ & $3.65 \mathrm{E}+01$ & $1.89 \mathrm{E}+01$ & 0.94 \\
\hline${ }^{89} \mathrm{Sr}$ & $7.00 \mathrm{E}+01$ & $4.76 \mathrm{E}+01$ & $4.66 \mathrm{E}+01$ & $7.45 \mathrm{E}+01$ & $1.35 \mathrm{E}+02$ & $4.66 \mathrm{E}+01$ & 0.67 \\
\hline${ }^{90} \mathrm{Sr}$ & $3.00 \mathrm{E}+00$ & $5.49 \mathrm{E}+00$ & $4.81 \mathrm{E}+00$ & $2.39 \mathrm{E}+00$ & $5.63 \mathrm{E}+00$ & $2.39 \mathrm{E}+00$ & 0.80 \\
\hline${ }^{95} \mathrm{Zr}$ & $2.00 \mathrm{E}+01$ & $3.57 \mathrm{E}+01$ & $1.54 \mathrm{E}+01$ & $2.15 E+01$ & $2.82 E+01$ & $1.54 \mathrm{E}+01$ & 0.77 \\
\hline${ }^{95} \mathrm{Nb}$ & $5.00 \mathrm{E}+01$ & $1.05 \mathrm{E}+02$ & $4.81 \mathrm{E}+01$ & $6.66 \mathrm{E}+01$ & $9.01 E+01$ & $4.81 \mathrm{E}+01$ & 0.96 \\
\hline${ }^{103} \mathrm{Ru}$ & $3.00 \mathrm{E}+01$ & $6.49 \mathrm{E}+01$ & $2.99 \mathrm{E}+01$ & $4.22 \mathrm{E}+01$ & $5.63 \mathrm{E}+01$ & $2.99 \mathrm{E}+01$ & 1.00 \\
\hline${ }^{106} \mathrm{Ru}$ & $3.00 \mathrm{E}+00$ & $5.10 \mathrm{E}+00$ & $2.33 \mathrm{E}+00$ & $4.08 \mathrm{E}+00$ & $4.83 \mathrm{E}+00$ & $2.33 \mathrm{E}+00$ & 0.78 \\
\hline${ }^{125} \mathrm{Sb}$ & $2.00 \mathrm{E}+01$ & $3.57 \mathrm{E}+01$ & $1.49 \mathrm{E}+01$ & $2.18 \mathrm{E}+01$ & $2.82 \mathrm{E}+01$ & $1.49 \mathrm{E}+01$ & 0.75 \\
\hline $131 \mid$ & $3.00 \mathrm{E}+00$ & $4.20 \mathrm{E}+00$ & $1.59 \mathrm{E}+00$ & $4.08 \mathrm{E}+00$ & $6.76 \mathrm{E}+00$ & $1.59 \mathrm{E}+00$ & 0.53 \\
\hline 132 & $2.00 \mathrm{E}+02$ & $2.55 \mathrm{E}+02$ & 1.15E+02 & $2.94 \mathrm{E}+02$ & 4.36E+02 & 1.15E+02 & 0.57 \\
\hline 133 & $2.00 \mathrm{E}+01$ & $1.59 \mathrm{E}+01$ & $7.11 \mathrm{E}+00$ & $2.01 E+01$ & $3.38 \mathrm{E}+01$ & $7.11 \mathrm{E}+00$ & 0.36 \\
\hline 134 & $5.00 \mathrm{E}+02$ & $8.21 \mathrm{E}+02$ & $3.83 \mathrm{E}+02$ & $7.91 \mathrm{E}+02$ & $9.01 \mathrm{E}+02$ & 3.83E+02 & 0.77 \\
\hline $135 \mid$ & $8.00 \mathrm{E}+01$ & $7.36 \mathrm{E}+01$ & $3.32 E+01$ & $9.04 \mathrm{E}+01$ & $1.47 \mathrm{E}+02$ & $3.32 E+01$ & 0.41 \\
\hline${ }^{134} \mathrm{Cs}$ & $1.00 \mathrm{E}+01$ & $6.49 \mathrm{E}+01$ & $2.87 \mathrm{E}+01$ & $2.01 E+01$ & $2.05 E+01$ & $2.01 \mathrm{E}+01$ & 2.01 \\
\hline${ }^{136} \mathrm{Cs}$ & $5.00 \mathrm{E}+01$ & $9.78 \mathrm{E}+01$ & $5.15 E+01$ & $9.04 \mathrm{E}+01$ & $1.13 \mathrm{E}+02$ & $5.15 \mathrm{E}+01$ & 1.03 \\
\hline${ }^{137} \mathrm{Cs}$ & $1.00 \mathrm{E}+01$ & $8.12 E+01$ & $4.15 \mathrm{E}+01$ & $2.88 \mathrm{E}+01$ & $2.94 \mathrm{E}+01$ & $2.88 \mathrm{E}+01$ & 2.88 \\
\hline${ }^{140} \mathrm{Ba}$ & $7.00 \mathrm{E}+01$ & $2.65 E+01$ & $1.36 \mathrm{E}+01$ & $2.04 \mathrm{E}+01$ & $2.65 \mathrm{E}+01$ & $1.36 \mathrm{E}+01$ & 0.19 \\
\hline${ }^{141} \mathrm{Ce}$ & $2.00 \mathrm{E}+01$ & $5.49 \mathrm{E}+01$ & $2.37 \mathrm{E}+01$ & $3.09 \mathrm{E}+01$ & $4.22 \mathrm{E}+01$ & 2.37E+01 & 1.18 \\
\hline
\end{tabular}

the currently applied domestic ECLs, as shown in Table 4.

The re-evaluated results for each age group showed that the child age group exhibited the lowest value for the tritium $\left({ }^{3} \mathrm{H}\right)$, radiocarbon $\left({ }^{14} \mathrm{C}\right)$, and iodine isotopes. This implies that the child age group is most significantly affected, among all age groups, when the air concentration of these radioactive materials is the same. The lowest values among the reevaluated results for each age group are 1.6 times and 1.36 times higher than the domestic ECLs for tritium $\left({ }^{3} \mathrm{H}\right)$ and radiocarbon $\left({ }^{14} \mathrm{C}\right)$, respectively, but are 0.36 to 0.77 times lower than the domestic ECLs for iodine isotopes.

Relative ratios of the CFR ECLs (labeled as 10CFR20) and the re-evaluated results via the two different direct calculation methods (labeled as Method-1 and Method-2, respectively) are shown in Figure 1. The resulting relative ratios largely differed depending on the radionuclides, but it was clearly shown that, for tritium $\left({ }^{3} \mathrm{H}\right)$ and radiocarbon $\left({ }^{14} \mathrm{C}\right)$, which significantly affect off-site radiological doses during the normal operation of nuclear power plants, the domestic ECLs were set lower, i.e., more conservatively. The re-evaluated results for each age group showed that radioiodine had

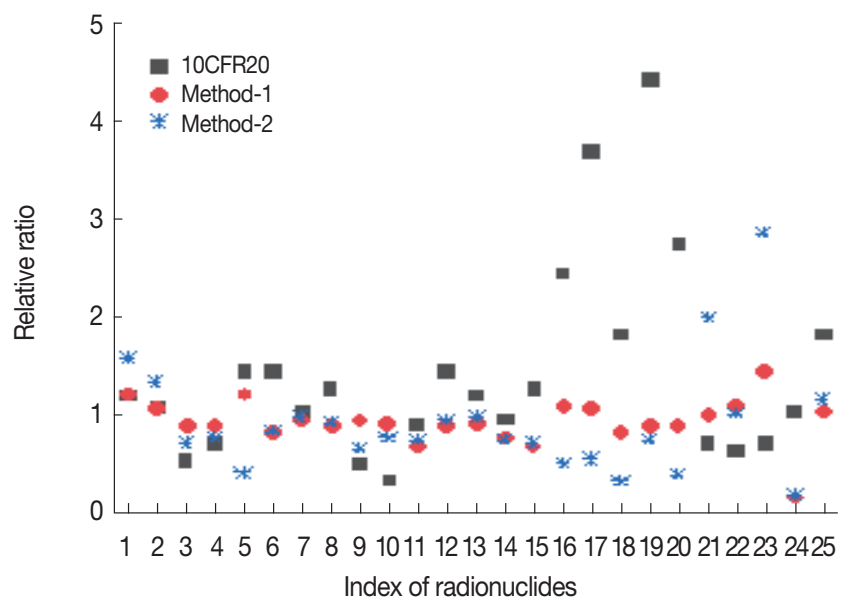

Fig. 1. Relative ratios of ECLs documented in 10CFR20 and reevaluated through direct calculations using two different methods, compared to ECLs documented in the NSSC's Notice. In the legend, "10CFR20" represents the relative ratios of ECLs documented in 10CFR20, and "Method-1" and "Method-2" represent the relative ratios of re-evaluated ECLs according to the method described in 10CFR20 and the method considering age groups, respectively (1: ${ }^{3} \mathrm{H}, 2:{ }^{14} \mathrm{C}, 3:{ }^{51} \mathrm{Cr}, 4:{ }^{54} \mathrm{Mn}, 5:{ }^{57} \mathrm{Co}, 6:{ }^{58} \mathrm{Co}, 7:{ }^{60} \mathrm{Co}, 8:{ }^{59} \mathrm{Fe}, 9:{ }^{89} \mathrm{Sr}$, 10: ${ }^{90} \mathrm{Sr}, 11:{ }^{95} \mathrm{Zr}, 12:{ }^{95} \mathrm{Nb}, 13:{ }^{103} \mathrm{Ru}, 14:{ }^{106} \mathrm{Ru}, 15:{ }^{125} \mathrm{Sb}, 16:{ }^{131}$, 17: ${ }^{132}\left|, 18:{ }^{133}\right|, 19:{ }^{134}\left|, 20:{ }^{135}\right|, 21:{ }^{134} \mathrm{Cs}, 22:{ }^{136} \mathrm{Cs}, 23:{ }^{137} \mathrm{Cs}, 24:$ $\left.{ }^{140} \mathrm{Ba}, 25:{ }^{141} \mathrm{Ce}\right)$. 
the lowest values, but nonetheless, the domestic ECLs for radioiodine were lower than the values of 10CFR20 and Method-1, respectively. Overall, the current domestic ECLs were most similar to the re-evaluated results using the method described in the CFR (i.e., Method-1).

\section{Conclusion}

Effluent Concentration Limits (ECLs) specified in the Notice by Korea's Nuclear Safety and Security Commission (NSSC) are designated to protect the public against the stochastic health effects of radiation arising from inhalation of airborne radioactive materials and the corresponding internal exposure. These ECLs, however, are indirectly estimated from Derived Air Concentrations (DACs) for radiation workers. In the present study, ECLs were directly calculated by reflecting dose coefficients based on radiation protection quantity introduced in Korea and the intrinsic breathing rates of Korean residents. These re-evaluated ECLs were compared not only with the domestic ECLs but also with ECLs specified in the Code of Federal Regulations (CFR).

The relative ratios of the re-evaluated ECLs to the currently applied domestic ECLs differed depending on the radionuclides, but it was clearly shown that, for tritium $\left({ }^{3} \mathrm{H}\right)$ and radiocarbon $\left({ }^{14} \mathrm{C}\right)$, which significantly affect radiological dose during the normal operation of nuclear power plants, the reevaluated ECLs were higher than the domestic ECLs. This implies that Korea uses more conservative standards. In the re-evaluated results for each age group, ${ }^{131}$ I (radioiodine), one of the most significant radionuclides, had the lowest values, but still, the domestic ECLs for radioiodine were lower than the ECLs given in the CFR and the re-evaluated ECLs determined using the method given in the CFR.

In the present study, ECLs were re-evaluated only for radionuclides possibly released to the environment during the normal operation of nuclear power plants. Therefore, a future study has to be conducted with more various types of radionuclides. The major findings of the present study will serve as basic data to help confirm the technical validity of ECLs and further establish new relevant standards going forward.

\section{Acknowledgements}

This work was support by Nuclear R\&D Programs of Ministry of Science and ICT of Korea (Grant No. 2017M2A8A4015251).

\section{References}

1. International Atomic Energy Agency. International basic safety standards for protection against ionizing radiation and for the safety of radiation sources. Safety Series No. 115. 1996;94.

2. Korean Advanced Energy Research Institute. Development of offsite radiological dose assessment model for a Kori site. KAERI/ NSC-397/89. 1989;29.

3. Korea Institute of Nuclear Safety. INDAC User's Manual. 1999; IV-25.

4. Korea Hydro \& Nuclear Power Co., Ltd. Radiation environmental impact assessment report on the construction project of ShinKori reactor 5 and 6. 2016;5.2-33.

5. U. S. Nuclear Regulatory Commission. Calculation of annual doses to man from routine releases of reactor effluents for the purpose of evaluating compliance with 10CFR part 50, Appendix I. Regulatory Guide 1.109. 1977;19-28. 